\title{
The effect of ozone therapy on experimental bone fracture healing in rats [abstract]
}

\author{
Arzu Irban, Serap Uslu, Arel Gereli, Elif Ilgaz Aydinlar, Pinar Elpen Karyemez, \\ Nurettin Luleci, Guldal Gulec Suyen
}

Department of Anesthesiology and Reanimation, Medipol Mega University. Medical School. Hospital Bagcilar, Istanbul

\section{ABSTRACT}

\section{OPEN ACCESS}

\section{Citation}

Irban A, Uslu S, Gereli A, Aydinlar El, Karyemez PE, Luleci $N$ et al. The effect of ozone therapy on experimental bone fracture healing in rats [abstract]. Proceedings of The World Conference on Ozone Therapy in Medicine,

Dentistry and Veterinary. Ancona (Italy). September 22nd - 23rd - 24th , 2017. J Ozone Ther. 2019;3(4):29. doi: 10.7203/ jo3t.3.4.2019.15511

\section{Academic Editor \\ Jose Baeza-Noci, \\ School of Medicine, Valencia University,} SPAIN

\section{Editor}

World Federation of Ozone Therapy,

Bolgna, ITALY

\section{Received}

June 17, 2019

\section{Accepted}

December 08, 2019

\section{Published}

December 30, 2019

\section{Intellectual Property}

Arzu Irban.

This is an open access article distributed under the terms of the Creative Commons Attribution License (CC BY 4.0), which permits unrestricted use, distribution, and reproduction in any medium, provided the original author and source are credited.

\section{Author Information} arzu.irban@medipol.com.tr
Background. In the literature, many beneficial effects are attributed ozone; it balances the oxidant-antioxidant system, leads to delivery of super enriched oxygen at a cellular level and optimizes cell function, etc.

Purpose. The aim of this study was to evaluate if there is a positive impact of ozone therapy on bone healing in an experimental fracture model in rats.

Material and Methods. After approval of experimental animal ethic committee, an open femoral fracture (ffx) was performed in 48 male Spraque Dawley rats. They were randomly divided into two groups: in Group $\mathrm{O}$, medical ozone/oxygen mixture $(500 \mathrm{mg} / \mathrm{kg}$ ) and in Group C, medical air in volume of $4 \mathrm{~mL}$ were given rectally for 3-days. At days 4,7 and 13 , eight rats from each group were euthanized, and histomorphometric and immunohistochemical bone tissue evaluation was undertaken from the femur sampling.

Results. Histomorphometrically, periost thickness was thicker, trabecular areas were larger, cartilaginous and new bone areas were smaller $(p<0.05$ for each) and TGF- $\beta$ expressions were more intense in Group $O(p<0.001$ for all times). Immuno-histochemically, a significant increase in VEGF expressions in day 7 and 13 ( $p<0.001$ for each) and higher B-catenin expressions were observed in Group $O$ at day 7 and 13 ( $p<0.001$ for each).

Conclusions. At the clinical application, we believe that ozone application will result in better and faster bone healing that leads to decrease in hospitality time, early return to work, decrease the incidence of complications. The current data indicate that ozone therapy could have positive impacts on bone healing process.

\section{References:}

1. Le AX, Miclau T, Hu D, Helms JA. Molecular aspects of healing in stabilized and non-stabilized fractures. J Orthop Res. 2001;19(1):78-84.

2. Wohl GR, Towler DA, Silva MJ. Stress fracture healing: fatigue loading of the rat ulna induces upregulation in expression of osteogenic and angiogenic genes that mimic the intramembranous portion of fracture repair. Bone. 2009;44(2):320-30. doi: 10.1016/j.bone.2008.09.010.

3. Yavropoulou MP, Yovos JG. The role of the Wnt signaling pathway in osteoblast commitment and differentiation. Hormones.

2007;6(4):279-294. 